\title{
Reclassification of 'Dactylosporangium variesporum' as Saccharothrix variisporea corrig. (ex Tomita et al. 1977) sp. nov., nom. rev.
}

\author{
Correspondence \\ Michael Goodfellow \\ m.goodfellow@ncl.ac.uk
}

\author{
Byung-Yong Kim, ${ }^{1}$ Roselyn Brown, ${ }^{1}$ David P. Labeda ${ }^{2}$ \\ and Michael Goodfellow ${ }^{1}$ \\ ${ }^{1}$ School of Biology, University of Newcastle, Newcastle upon Tyne, NE1 7RU, UK
${ }^{2}$ Microbial Genomics and Bioprocessing Research Unit, National Center for Agricultural Utilization
Research, USDA-Agricultural Research Service, Peoria, IL 61604, USA
}

In the course of a polyphasic study it was observed that 'Dactylosporangium variesporum' NRRL B-16296 is misclassified in the genus Dactylosporangium as it exhibits properties consistent with its assignment to the genus Saccharothrix. Phylogenetic analyses based on 16S rRNA gene sequences show that the strain falls within the evolutionary radiation of the genus Saccharothrix, a result which is supported by corresponding chemotaxonomic and morphological markers. The strain is phylogenetically most closely, albeit loosely, related to Saccharothrix espanaensis, but can be readily distinguished from this and other species of the genus Saccharothrix with validly described names by using a range of phenotypic properties. The combined genotypic and phenotypic data demonstrate conclusively that this strain should be classified as a new species in the genus Saccharothrix for which the name Saccharothrix variisporea sp. nov. is proposed. The

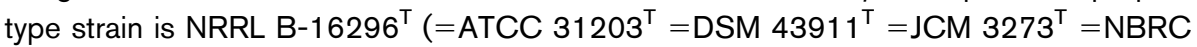
$\left.14104^{\mathrm{T}}\right)$.
'Dactylosporangium variesporum' sp. nov. was proposed by Tomita et al. (1977) to accommodate a strain isolated from a soil sample collected in India which they considered to have chemical and morphological properties consistent with its assignment to the genus Dactylosporangium. The micro-organism, strain D409-5, produces capreomycin and was reported by Tomita and his colleagues to form fingershaped sporangia, singly, in pairs or in clusters on substrate hyphae, and to contain meso-diaminopimelic acid in the cell wall peptidoglycan and galactose, mannose and rhamnose in whole-cell hydrolysates. Uchida \& Seino (1997), however, questioned the placement of this strain in the genus Dactylosporangium as they were unable to observe sporangia and found that the peptidoglycan contained $\mathrm{N}$-glycolated as opposed to $\mathrm{N}$-acetylated muramic acid moieties.

When 'D. variesporum' NRRL B-16296 was included in a study designed to clarify the taxonomy of species of the genus Dactylosporangium with invalidly described names, it was found to have properties consistent with its assignment to the genus Saccharothrix. In the present investigation, strain NRRL B-16296 ${ }^{\mathrm{T}}$ (=strain D409-5) was the subject of

The GenBank/EMBL/DDBJ accession number for the $16 \mathrm{~S}$ rRNA sequence of strain NRRL B-16296 ${ }^{\top}$ is GQ917213.

A supplementary figure is available with the online version of this paper. a polyphasic study which showed that it represents a novel species of the genus Saccharothrix for which the name Saccharothrix variisporea sp. nov. is proposed.

'D. variesporum' NRRL B-16296 and the equivalent strain DSM 43911 were maintained at $-20{ }^{\circ} \mathrm{C}$ as glycerol suspensions $(20 \%, \mathrm{v} / \mathrm{v})$. Biomass for $16 \mathrm{~S}$ rRNA gene sequence analyses of these strains and for the chemotaxonomic analyses of strain NRRL B-16296 ${ }^{\mathrm{T}}$ was prepared in modified Bennett's broth (Jones, 1949) at 150 r.p.m. in shake flasks for 21 days at $28{ }^{\circ} \mathrm{C}$. Cells were checked for purity and harvested by centrifugation. Biomass for chemotaxonomic analysis of strain NRRL B-16296 ${ }^{\mathrm{T}}$ was washed twice in distilled water and freeze-dried. Cells collected for DNA isolation and sequencing of 16S rRNA genes were washed in $\mathrm{NaCl} / \mathrm{EDTA}$ buffer (0.1M EDTA, $0.1 \mathrm{M} \mathrm{NaCl}, \mathrm{pH} 8.0$ ) and stored at $-20{ }^{\circ} \mathrm{C}$.

Preparation of genomic DNA, amplification and direct sequencing of the purified PCR products of $16 \mathrm{~S}$ rRNA genes prepared from strains NRRL B-16296 ${ }^{\mathrm{T}}$ and DSM $43911^{\mathrm{T}}$ were performed after Tan et al. (2006). The resultant, almost complete, 16S rRNA gene sequences (1458 nt) were aligned manually, using the jPHYDIT program (Jeon et al., 2005), against corresponding sequences of the type strains of species of the genus Saccharothrix retrieved from the GenBank database. Phylogenetic trees were inferred using the neighbour-joining (Saitou \& Nei, 1987), minimum-evolution and 
maximum-parsimony algorithms (Takahashi \& Nei, 2000) from the MEGA 3.1 program (Kumar et al., 2004). The evolutionary distance model of Jukes \& Cantor (1969) was used to generate an evolutionary distance matrix for the neighbour-joining algorithm. The topologies of the resultant trees were evaluated by bootstrap analysis (Felsenstein, 1985) based on 1000 resamplings of the neighbour-joining dataset. The root position of the neighbour-joining tree was obtained using Pseudonocardia thermophila IMSNU 20112 as the outgroup.

Identical $16 \mathrm{~S}$ rRNA gene sequences were obtained for ' $D$. variesporum' NRRL B-16296 and DSM 43911; hence only the sequence for strain NRRL B-16296 was deposited in GenBank (GQ917213) and is considered further. It can be seen in Fig. 1 that this strain falls within the evolutionary radiation of the genus Saccharothrix based on the phylogenetic analysis of $16 \mathrm{~S}$ rRNA genes. A subclade supported by all of the tree-making algorithms and by a bootstrap value of $61 \%$ is formed by this strain and the type strains of Saccharothrix espanaensis, Saccharothrix mutabilis subsp. capreolus and S. mutabilis subsp. mutabilis. Strain NRRL B-16296 ${ }^{\mathrm{T}}$ and S. mutabilis subsp. capreolus NRRL $2773^{\mathrm{T}}$ are reported to produce the antibiotic capreomycin, though NRRL B-16296 ${ }^{\mathrm{T}}$ was most closely related to S. espanaensis NRRL 15764 $4^{\mathrm{T}}$; the two strains shared a $16 \mathrm{~S}$ rRNA gene similarity of $98.9 \%$, a value which corresponded to $16 \mathrm{nt}$ differences at 1446 locations. The corresponding values between strain 'NRRL B-16296' ' and the type strains of $S$. mutabilis subsp. capreolus and S. mutabilis subsp. mutabilis were $98.5 \%$ (21 nt differences at 1425 locations) and $98.8 \%$ (18 nt differences at 1430 locations), respectively. The 16S rRNA gene sequence similarities between strain NRRL B- $16296^{\mathrm{T}}$ and the type strains of the remaining species of the genus Saccharothrix ranged from 97.5\% (with Saccharothrix violaceirubra) to $98.5 \%$ (with Saccharothrix australiensis). The 16S rRNA gene of strain NRRL B- $16296^{\mathrm{T}}$ contains the unique oligonucleotide signature characteristic for members of the genus Saccharothrix (Labeda \& Kroppenstedt, 2007).

Chemotaxonomic studies were undertaken to confirm that strain NRRL B-16296 ${ }^{\mathrm{T}}$ exhibited a chemical profile which supported its classification in the genus Saccharothrix.
Standard procedures were used to extract and analyse the isomers of diaminopimelic acid (Staneck \& Roberts, 1974), isoprenoid quinones (Collins, 1994), muramic acid type (Uchida et al., 1999), polar lipids (Minnikin et al., 1984) and whole-organism sugars (Schaal, 1985), using appropriate controls. Cellular fatty acids were extracted, methylated and analysed by GC using the standard Sherlock MIDI (Microbial Identification) system (Sasser, 1990) and mycolic acids sought using the TLC procedure described by Minnikin et al. (1975).

The strain contained meso-diaminopimelic acid (wall chemotype III sensu; Lechevalier \& Lechevalier 1970), $\mathrm{N}$-acetylated muramic acid moieties, galactose, mannose and rhamnose as diagnostic whole-organism sugars, tetrahydrogenated menaquinones with nine isoprene units $\left(\mathrm{MK}-9\left[\mathrm{H}_{4}\right]\right)$ as the predominant menaquinone, and diphosphatidylglycerol, phosphatidylethanolamine, phosphatidylinositol and phosphatidylglycerol as major polar lipids (phospholipid pattern type II sensu; Lechevalier et al. 1977) together with a trace of phosphatidylinositol mannoside and single unknown aminolipid and phospholipid components. The predominant fatty acids were 13-methyltetradecanoic (iso- $\mathrm{C}_{15: 0}$ ), 14-methylpentadecanoic (iso- $\mathrm{C}_{16: 0}$ ) and 14-methylhexadecanoic (anteiso$\mathrm{C}_{17: 0}$ ) acids; mycolic acids were not present. All of these properties are in line with the classification of the strain in the genus Saccharothrix (Labeda et al., 1984; Otoguro et al., 2009).

The DNA G + C content of strain NRRL B- $16296^{\mathrm{T}}$ was determined by using the procedure described by Gonzalez \& Saiz-Jimenez (2005) and found to be $74 \mathrm{~mol} \%$. DNADNA relatedness studies were not carried out between strain NRRL B-16296 and its closest phylogenetic neighbours as type strains of species of the genus Saccharothrix with similar $16 \mathrm{~S}$ rRNA gene sequences have DNA-DNA hybridization values well below the $70 \%$ cut-off point recommended by Wayne et al. (1987) for the circumscription of strains that belong to the same genomic species. Thus, the type strains of $S$. espanaensis and S. mutabilis have a $16 \mathrm{~S}$ rRNA gene similarity of $99.0 \%$ but a DNADNA relatedness value of $0 \%$ (Labeda \& Lechevalier, 1989) whereas the type strains of Saccharothrix syringae and

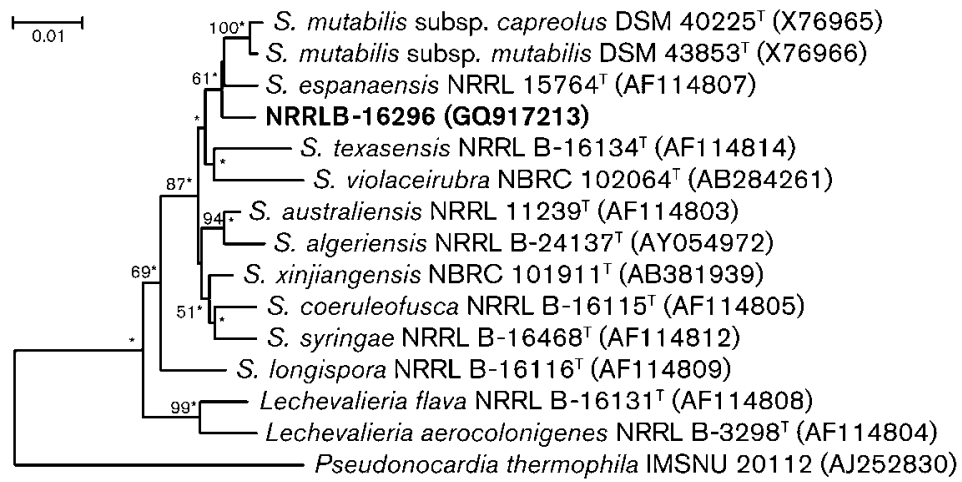

Fig. 1. Neighbour-joining tree based on almost complete 16S rRNA gene sequences showing the position of strain NRRL B-16296 ${ }^{\top}$ in relation to members of the genus Saccharothrix. Numbers on branches indicate percentage bootstrap values from 1000 replicates (only values $>50 \%$ are shown). Asterisks indicate the branches that were also recovered in the minimum-evolution and maximum-parsimony trees. Bar, 0.01 substitutions per nucleotide position. 
Saccharothrix xinjiangensis share a $16 \mathrm{~S}$ rRNA gene similarity of $99.1 \%$ but have a DNA-DNA relatedness value of only $50 \%$ (Hu et al., 2004). Similarly, Saccharothrix algeriensis NRRL $\mathrm{B}-24137^{\mathrm{T}}$ and S. australiensis NRRL $11239^{\mathrm{T}}$ have a $16 \mathrm{~S}$ rRNA gene similarity of $98.8 \%$ and a DNA-DNA relatedness of $55.9 \%$ (Zitouni et al., 2004).

The gross morphological properties of strain NRRL B$16296^{\mathrm{T}}$ were observed on plates of tryptone-yeast extract, yeast extract-malt extract, oatmeal, inorganic salts-starch, glycerol-asparagine, peptone-yeast extract-iron and tyrosine agar plates (ISP media 1-7, respectively; Shirling \& Gottlieb, 1966) which were incubated for 21 days at $28^{\circ} \mathrm{C}$. The strain grew well on all of these media, apart from peptone-yeast extract-iron agar (PYEA), producing a light yellow to light reddish-brown substrate mycelium and rudimentary aerial hyphae on glycerol-asparagine, oatmeal and tyrosine agars. Melanin pigments were formed on tyrosine agar, but not on PYEA.
Morphological characteristics were observed by examining gold-coated, dehydrated preparations from a 14-day-old culture of strain NRRL B-16296 ${ }^{\mathrm{T}}$ grown on inorganic saltsstarch agar at $28{ }^{\circ} \mathrm{C}$, using a Cambridge Stereoscan 240 scanning electron microscope and the procedure described by O'Donnell et al. (1993). The organism produced a branched substrate mycelium and spores on synnematalike structures, but there was no evidence of spore vesicles (Supplementary Fig. S1 available in IJSEM online).

Strain NRRL B-16296 ${ }^{\mathrm{T}}$ was examined for a broad range of phenotypic properties using standard media and methods described by Goodfellow et al. (1997). It can be seen from Table 1 that the strain can be clearly distinguished from the type strains of species of the genus Saccharothrix, including its nearest neighbours, S. espanaensis NRRL $15764^{\mathrm{T}}$ and the type strains of the two subspecies of $S$. mutabilis, by using a combination of phenotypic properties. Strain B-16296 ${ }^{\mathrm{T}}$, unlike the type strain of $S$. espanaensis, grows at $45^{\circ} \mathrm{C}$ and

Table 1. Phenotypic properties which separate strain NRRL B-16296 ${ }^{\top}$ from the type strains of species of the genus Saccharothrix

Taxa: 1, strain NRRL B-16296 ${ }^{\mathrm{T}}$; 2, Saccharothrix algeriensis NRRL B-24137 ${ }^{\mathrm{T}}$; 3, S. australiensis NRRL $11239^{\mathrm{T}}$; 4, S. coeruleofusca DSM 43679 ${ }^{\mathrm{T}}$; 5 , S. espanaensis NRRL $15764^{\mathrm{T}}$; 6, S. longispora DSM $43749^{\mathrm{T}}$; 7, S. mutabilis subsp. capreolus DSM 40225 ; 8, S. mutabilis subsp. mutabilis NRRL B-16077 ; 9, S. syringae DSM 43886 ${ }^{\mathrm{T}}$; 10, S. texasensis NRRL B-16134 ${ }^{\mathrm{T}}$; 11, S. violaceirubra KCTC $19326^{\mathrm{T}}$; 12 , S. xinjiangensis NBRC $101911^{\mathrm{T}}$. Data for the reference strains were taken from Labeda (2002), Zitouni et al. (2004), Hu et al. (2004) and Otoguro et al. (2009). +, Positive; -, negative; ND, no data available; $w$, weakly positive; $v$, variable.

\begin{tabular}{|c|c|c|c|c|c|c|c|c|c|c|c|c|}
\hline Characteristic & 1 & 2 & 3 & 4 & 5 & 6 & 7 & 8 & 9 & 10 & 11 & 12 \\
\hline \multicolumn{13}{|l|}{ Decomposition of: } \\
\hline Adenine & - & - & - & - & - & + & - & - & - & - & - & ND \\
\hline Hypoxanthine & + & - & - & - & + & - & + & + & - & + & - & ND \\
\hline Starch & + & - & - & + & - & + & + & + & + & + & - & + \\
\hline Tyrosine & + & + & + & + & - & + & - & + & + & + & + & + \\
\hline Nitrate reduction & - & + & + & - & $\mathrm{w}$ & + & - & + & - & + & + & - \\
\hline \multicolumn{13}{|l|}{ Assimilation of: } \\
\hline Citrate & - & + & - & - & $\mathrm{V}$ & + & + & + & - & - & - & - \\
\hline Lactate & - & $\mathrm{ND}$ & $\mathrm{w}$ & - & + & + & - & + & - & + & - & - \\
\hline Malate & + & $\mathrm{ND}$ & + & - & + & + & + & + & + & + & - & ND \\
\hline \multicolumn{13}{|l|}{ Utilization of: } \\
\hline Arabinose & + & - & - & + & - & + & + & + & + & + & - & + \\
\hline Dextrin & + & - & + & + & - & + & + & + & + & + & - & ND \\
\hline Inositol & + & - & - & - & - & - & + & + & - & + & - & ND \\
\hline Lactose & + & - & - & + & - & + & - & + & + & + & - & + \\
\hline Melibiose & + & - & - & - & - & - & + & + & + & + & - & + \\
\hline Methyl $\alpha$-D-glucoside & + & - & - & + & - & - & - & + & - & + & - & + \\
\hline Raffinose & + & - & - & + & - & - & - & + & + & - & - & + \\
\hline Rhamnose & + & - & - & + & - & + & - & - & + & + & - & + \\
\hline Salicin & + & $\mathrm{ND}$ & - & + & - & $\mathrm{ND}$ & + & + & $\mathrm{w}$ & + & - & ND \\
\hline Sorbitol & - & - & + & + & - & - & - & - & - & - & - & - \\
\hline Sucrose & + & - & - & + & + & + & - & + & + & + & + & + \\
\hline D-Xylose & + & - & - & + & $\mathrm{V}$ & + & + & + & + & + & - & + \\
\hline \multicolumn{13}{|l|}{ Growth in presence of: } \\
\hline $4 \% \mathrm{NaCl}(\mathrm{w} / \mathrm{v})$ & + & + & + & + & + & + & + & - & + & - & - & - \\
\hline $5 \% \mathrm{NaCl}(\mathrm{w} / \mathrm{v})$ & - & - & - & + & - & + & + & - & + & - & - & - \\
\hline $37^{\circ} \mathrm{C}$ & + & + & + & + & + & + & + & + & + & + & - & + \\
\hline $45^{\circ} \mathrm{C}$ & $\mathrm{w}$ & + & + & + & - & - & + & + & + & - & - & + \\
\hline
\end{tabular}


degrades starch and tyrosine, and utilizes sugars such as $(+)$-L-arabinose, dextrin, myo-inositol, lactose, melibiose, $(+)$-D-raffinose and (+)-D-xylose as sole sources of carbon for energy and growth. Additional phenotypic properties of the strain are given in Table 1 and in the species description.

The genotypic and phenotypic data clearly demonstrate that strain NRRL B-16296 ${ }^{\mathrm{T}}$ is misclassified in the genus Dactylosporangium as its phylogenetic position and chemotaxonomic profile are typical of members of the genus Saccharothrix. Moreover, the phylogenetic data show convincingly that the strain forms a new centre of taxonomic variation within this genus. It is, therefore, proposed that strain NRRL B-16296 ${ }^{\mathrm{T}}$ be classified in the genus Saccharothrix as a new species, Saccharothrix variisporea sp. nov.

\section{Description of Saccharothrix variisporea sp. nov.}

Saccharothrix variisporea (va.ri.i.spo're.a. L. adj. varius diverse, different, various; Gr. n. spora a seed, in microbiology, a spore; L. suff. eus, $-a$, $-u m$, suffix with various meanings, but in general, made of or belongs to; N.L. fem. adj. variisporea with different spores).

The description is based on data taken from the present study and from the earlier work of Tomita et al. (1977). Aerobic, Gram-positive actinomycete which forms branched, light orange coloured mycelia on inorganic salts-starch and oatmeal agars. Grows well between 30 and $37^{\circ} \mathrm{C}$, from $\mathrm{pH} 4$ to 10 , and optimally around $\mathrm{pH} 7$. Positive for aesculin and allantoin hydrolysis, catalase, coagulation and peptonization of milk, and for hydrogen sulfide and urease production, but negative for nitrate reduction. Degrades arbutin, casein, DNA, elastin, gelatin, Tweens 40, 60 and 80, uric acid and xylan, but not cellulose, chitin, guanine, pectin, RNA, tributyrin, Tween 20 or xanthine. Cellobiose, (+)-D-galactose, (-)-Dglucose, glycerol, glycogen, inulin, mannitol, maltose, $(+)$-D-mannose, (-)-D-ribose, starch and trehalose (at $1.0 \%, \mathrm{w} / \mathrm{v})$, and (+)-L-tartaric acid, (-)-L-malic acid, propionic acid, pyruvic acid and uric acid (at $0.1 \%, \mathrm{w} / \mathrm{v})$ are used as sole carbon sources, but not adonitol, (+)-Darabitol, dulcitol, (-)-D-sorbitol, (-)-L-sorbose or xylitol (at $1.0 \%, \mathrm{w} / \mathrm{v})$ or $(+)$-L-lactic acid, oxalic acid or urea (at $0.1 \%$, w/v). Resistant $\left(\mu \mathrm{g} \mathrm{ml} \mathrm{m}^{-1}\right.$ ) to ampicillin (4), cephaloridine (2), clindamycin (8), gentamicin (8), kanamycin (8), lincomycin (8), oxytetracycline (8), penicillin G (2), tylosin (8) and vancomycin (2), but sensitive to ciprofloxacin (2), chloramphenicol (8), novobiocin (8), rifampicin (16), streptomycin (4) and tetracycline (8). Growth occurs in the presence of $4 \%(\mathrm{w} / \mathrm{v}) \mathrm{NaCl}$ and $0.05 \%$ lysozyme, but not in the presence of $5 \% \mathrm{NaCl}$. Additional phenotypic properties are shown in Table 1 and in the main text. The predominant fatty acids are iso- $\mathrm{C}_{16: 0}$, anteiso- $\mathrm{C}_{17: 0}$, iso- $\mathrm{C}_{15: 0}$, 9-methyl $\mathrm{C}_{16: 0}$, iso- $\mathrm{C}_{17: 0}$, iso$\mathrm{C}_{16: 1} \mathrm{H}, \mathrm{C}_{17: 1} \omega 6 c, \mathrm{C}_{16: 1} 2-\mathrm{OH}, \mathrm{C}_{16: 1} \omega 7 c$, anteiso- $\mathrm{C}_{15: 0}$, $\mathrm{C}_{17: 1} \omega 8 c$ and anteiso- $\mathrm{C}_{17: 1} \mathrm{C}$. The DNA G $+\mathrm{C}$ content of the type strain is $74 \mathrm{~mol} \%$.
The type strain, NRRL B-16296 ${ }^{\mathrm{T}}\left(=\mathrm{ATCC} 31203^{\mathrm{T}}=\mathrm{DSM}\right.$ $43911^{\mathrm{T}}=\mathrm{JCM} 3273^{\mathrm{T}}=$ NBRC $14104^{\mathrm{T}}$ ), was isolated from a soil sample from India.

\section{Acknowledgements}

We are indebted to Professor Jean Euzéby for providing the correct etymology for the species epithet.

\section{References}

Collins, M. D. (1994). Isoprenoid quinones. In Chemical Methods in Prokaryotic Systematics, pp. 265-309. Edited by M. Goodfellow \& A. G. O'Donnell. Chichester: Wiley.

Felsenstein, J. (1985). Confidence limits on phylogenies: an approach using the bootstrap. Evolution 39, 783-791.

Gonzalez, J. M. \& Saiz-Jimenez, C. (2005). A simple fluorimetric method for the estimation of DNA-DNA relatedness between closely related microorganisms by thermal denaturation temperatures. Extremophiles 9, 75-79.

Goodfellow, M., Brown, A. B., Cai, J., Chun, J. \& Collins, M. D. (1997). Amycolatopsis japonicum sp. nov., an actinomycete producing (S,S)N,N'-ethylenediaminedisuccinic acid. Syst Appl Microbiol 20, 78-84.

Hu, Y.-T., Zhou, P.-J., Zhou, Y.-G., Liu, Z.-H. \& Liu, S.-J. (2004). Saccharothrix xinjiangensis sp. nov., a pyrene-degrading actinomycete isolated from Tianchi Lake, Xinjiang, China. Int J Syst Evol Microbiol 54, 2091-2094.

Jeon, Y.-S., Chung, H., Park, S., Hur, I., Lee, J.-H. \& Chun, J. (2005). jPHYDIT: a JAVA-based integrated environment for molecular phylogeny of ribosomal RNA sequences. Bioinformatics 21, 3171-3173.

Jones, K. L. (1949). Fresh isolates of actinomycetes in which the presence of sporogenous aerial mycelia is a fluctuating characteristic. J Bacteriol 57, 141-145.

Jukes, T. H. \& Cantor, C. R. (1969). Evolution of protein molecules. In Mammalian Protein Metabolism, vol. 3, pp. 21-132. Edited by H. N. Munro. New York: Academic Press.

Kumar, S., Tamura, K. \& Nei, M. (2004). MEGA3: integrated software for molecular evolutionary genetics analysis and sequence alignment. Brief Bioinform 5, 150-163.

Labeda, D. P. (2002). The family Actinosynnemataceae. In The Prokaryotes, 3rd edn, pp. 654-668. Edited by M. Dworkin, S. Falkow, E. Rosenberg, K. Schleifer \& E. Stackebrandt. New York: Springer.

Labeda, D. P. \& Kroppenstedt, R. M. (2007). Proposal of Umezawaea gen. nov., a new genus of the Actinosynnemataceae related to Saccharothrix, and transfer of Saccharothrix tangerinus Kinoshita et al. 2000 as Umezawaea tangerina gen. nov., comb. nov. Int J Syst Evol Microbiol 57, 2758-2761.

Labeda, D. P. \& Lechevalier, M. P. (1989). Amendment of the genus Saccharothrix Labeda et al. 1984 and descriptions of Saccharothrix espanaensis sp. nov., Saccharothrix cryophilis sp. nov., and Saccharothrix mutabilis comb. nov. Int J Syst Bacteriol 39, 420-423.

Labeda, D. P., Testa, R. T., Lechevalier, M. P. \& Lechevalier, H. A. (1984). Saccharothrix: a new genus of the Actinomycetales related to Nocardiopsis. Int J Syst Bacteriol 34, 426-431.

Lechevalier, M. P. \& Lechevalier, H. (1970). Chemical composition as a criterion in the classification of aerobic actinomycetes. Int J Syst Bacteriol 20, 435-443.

Lechevalier, M. P., De Bièvre, C. \& Lechevalier, H. A. (1977). Chemotaxonomy of aerobic actinomycetes: phospholipid composition. Biochem Syst Ecol 5, 249-260. 
Minnikin, D. E., Alshamaony, L. \& Goodfellow, M. (1975). Differentiation of Mycobacterium, Nocardia, and related taxa by thin-layer chromatographic analysis of whole-organism methanolysates. J Gen Microbiol 88, 200-204.

Minnikin, D. E., O'Donnell, A. G., Goodfellow, M., Alderson, G., Athalye, M., Schaal, A. \& Parlett, J. H. (1984). An integrated procedure for the extraction of bacterial isoprenoid quinones and polar lipids. J Microbiol Methods 2, 233-241.

O’Donnell, A. G., Falconer, C., Goodfellow, M., Ward, A. C. \& Williams, E. (1993). Biosystematics and diversity amongst novel carboxydotrophic actinomycetes. Antonie van Leeuwenhoek 64, 325-340.

Otoguro, M., Tamura, T., Suzuki, K. \& Hayakawa, M. (2009). Saccharothrix violaceirubra sp. nov., isolated from soil and plant litter. Int J Syst Evol Microbiol 59, 1504-1507.

Saitou, N. \& Nei, M. (1987). The neighbor-joining method: a new method for reconstructing phylogenetic trees. Mol Biol Evol 4, 406-425.

Sasser, M. (1990). Identification of Bacteria by Gas Chromatography of Cellular Fatty Acids, MIDI Technical Note 101. Newark, DE: MIDI Inc.

Schaal, K. P. (1985). Identification of clinically significant actinomycetes and related bacteria using chemical techniques. In Chemical Methods in Bacterial Systematics, pp. 359-381. Edited by M. Goodfellow \& D. E. Minnikin. London: Academic Press.

Shirling, E. B. \& Gottlieb, D. (1966). Methods for characterization of Streptomyces species. Int J Syst Bacteriol 16, 313-340.

Staneck, J. L. \& Roberts, G. D. (1974). Simplified approach to identification of aerobic actinomycetes by thin-layer chromatography. Appl Microbiol 28, 226-231.
Takahashi, K. \& Nei, M. (2000). Efficiencies of fast algorithms of phylogenetic inference under the criteria of maximum parsimony, minimum evolution and maximum likelihood when a large number of sequences are used. Mol Biol Evol 17, 1251-1258.

Tan, G. Y. A., Ward, A. C. \& Goodfellow, M. (2006). Exploration of Amycolatopsis diversity in soil using genus-specific primers and novel selective media. Syst Appl Microbiol 29, 557-569.

Tomita, K., Kobaru, S., Hanada, M. \& Tsukiura, H. (1977). Fermentation process. U.S. Patent 4026766, May 31.

Uchida, K. \& Seino, A. (1997). Intra- and intergeneric relationships of various actinomycete strains based on the acyl types of the muramyl residue in cell wall peptidoglycans examined in a glycolate test. Int $J$ Syst Bacteriol 47, 182-190.

Uchida, K., Kudo, T., Suzuki, K. \& Nakase, T. (1999). A new rapid method of glycolate test by diethyl ether extraction, which is applicable to a small amount of bacterial cells of less than one milligram. J Gen Appl Microbiol 45, 49-56.

Wayne, L. G., Brenner, D. J., Colwell, R. R., Grimont, P. A. D., Kandler, O., Krichevsky, M. I., Moore, L. H., Moore, W. E. C., Murray, R. G. E. \& other authors (1987). International Committee on Systematic Bacteriology. Report of the ad hoc committee on reconciliation of approaches to bacterial systematics. Int J Syst Bacteriol 37, 463464.

Zitouni, A., Lamari, L., Boudjella, H., Badji, B., Sabaou, N., Gaouar, A., Mathieu, F., Lebrihi, A. \& Labeda, D. P. (2004). Saccharothrix algeriensis sp. nov., isolated from Saharan soil. Int J Syst Evol Microbiol 54, 1377-1381. 